\title{
No Pressure
}

National Cancer Institute

\section{Source}

National Cancer Institute. No Pressure. NCI Thesaurus. Code C64243.

Unintended complete loss of pressure, compromising the device's intended function. 